\title{
Acute toxicity, antipyretic and antinociceptive study of the crude saponin from an edible vegetable: Vernonia amygdalina leaf
}

\author{
Paul Chukwuemeka ADIUKWU ${ }^{1 *}$, Agaba AMON $^{1}$, Grace NAMBATYA $^{2}$, Bulus ADZU ${ }^{4}$, \\ Lawrence IMANIRAMPA ${ }^{1}$, Silvano TWINOMUJUNI ${ }^{1}$, Osbert TWIKIRIZE ${ }^{1}$, \\ Martin AMANYA ${ }^{1}$, Joseph Obiezuchukwujekwu EZEONWUMELU ${ }^{3}$, Joseph OLORO ${ }^{1}$, \\ Godwin Aiyabalu OKORUWA ${ }^{3}$ and Barbra KATUSIIME ${ }^{1}$ \\ ${ }^{1}$ Pharmacy/Pharmacology Department, Faculty of Medicine, Mbarara University of Science \& Technology, \\ Uganda, P.O. Box 1410 Uganda. \\ ${ }^{2}$ Natural Chemotherapeutic Research Laboratories Kampala, P.O Box 4864 Kampala, Uganda. \\ ${ }^{3}$ School of Pharmacy Kampala International University Western Campus, P.O. Box 71 Bushenyi, Uganda. \\ ${ }^{4}$ Department of Pharmacology \& Toxicology, National Institute of Pharmaceutical Research \& Development, \\ $P M B$ 21, Abuja Nigeria. \\ *Corresponding author, E-mail: paulemy@must.ac.ug; Tel: +256705335782
}

\begin{abstract}
Vernonia amygdalina is commonly used for food and health purposes. Processing of the leaf for food is aimed at removing bitter tasting antinutritional principles like saponins. This study was designed to determine the antipyretic and antinociceptive property of the crude saponin from Vernonia amygdalina leaf. Standard procedure for antipyretic study using Saccharomyces cerevisiae induced pyrexia in rats; and acetic acid induced writhe, hot plate and cold tail flick tests for antinociceptive study in mice were used. Data for the crude saponin showed significant $(P \leq 0.05)$ dose dependent anal temperature decrease. The antinociceptive data in mice was significant $(P \leq 0.05)$ in the writhing test contrary to the cold tail flick test. In acute toxicity study, an $\mathrm{LD}_{50}$ of $5.1523 \mathrm{~g} / \mathrm{kg}$ using oral route indicated it was practically non-toxic. Finding suggests that Vernonia amygdalina leaf prepared as diet could be of potential benefit to ailing persons with fever and/or pains, if processing technique adopts minimal loss of principles like saponins.

(C) 2012 International Formulae Group. All rights reserved.
\end{abstract}

Keywords: Mice, oral, pain, pyrexia, rat.

\section{INTRODUCTION}

Beyond their ready source as food, edible plants have over the years been demonstrated to possess medicinal value. Vegetables commonly eaten as food have been shown to be also beneficial in herbal therapy. The result of a study covering more than 220,000 people concluded that one and one half servings of green leafy vegetables per day, lowers the risk of Type II diabetes by 14\% (Patrice et al., 2010).

Vernonia amygdalina, a local vegetable in Uganda, Nigeria and other African countries is widely used either as food or 
herbal medicine (Izevbigie, 2005). Grown in a range of ecological zones in Africa and the Arabian Peninsula (Bonsi et al., 1995), the plant is commonly referred to as bitter leaf. Locally, it is called "omubirizi" or "omululuza" (West and Central Uganda); "olusia" (Luo, Kenya); or "ewuro", "etidot" and "olugbo" (Southern Nigeria). In Southern Ethiopia, dairy farmers feed the boiled leaves to their stock during the dry period, and also to broilers as diet substitute (Bonsi et al., 1995).

Studies have indicated numerous phytochemicals to be present in the leaf extract of this plant (Izevbigie, 2005). The bitter taste of the leaf has been attributed to the presence of anti-nutritive principles like saponins, alkaloids, tannins and glycosides (Buttler and Bailey, 1973). Perhaps, the mode of preparing the leaves for human consumption which involves the socking and washing in warm water is aimed at reducing these bitter tasting.

Saponins are glycosides widely distributed in plants. They are characterized by their structure which contains one or more sugar chains on a triterpene or steroid aglycone backbone also called sapogenin. The number of sugar chains in their structure determines if it is monodesmosidic (single sugar), bidesmosidic (double sugar) or tridesmosidic (trible sugar) saponin. The type of aglycone, respect to the nature and number of the functional group, as well as, the nature of the sugars, can vary in diverse groups of saponin compounds. While evidence has shown that the main non-food sources of saponins used in health and industrial applications include the soap bark tree, Medicago sativa, Aesculus hippocastanum, Glycyrrhiza glabra, the main dietary sources of saponins are the dicotyledon like legumes, (Güçlü-Ustündağ and Mazza, 2007).

Saponins in foods have traditionally been considered bitter and unpleasant (Izevbigie, 2005). In some cases this has limited their use and therefore, most of the earlier research on processing has targeted their removal to facilitate human consumption (Ridout, 1991). Food and non-food sources of saponins have, however, come into renewed focus in recent years due to increasing evidence of their health benefits (Shi et al., 2004). Recent research which showed saponins as active component in many herbal medicines also highlighted their contributions to the health benefit of foods (Liu and Henkel, 2002). As such, the commercial potential of saponins has resulted in the development of new processing strategies (Muir et al., 2002). In line with this recent fact, saponin containing in herbs like $V$. amygdalina leaves prepared as food, may be of potential benefit to sick persons if a processing strategy that limits to a minimum, the loss of saponin is adopted. The objective of this study was therefore aimed at investigating the crude saponin from Vernonia amygdalina leaf aqueous extract for antinociceptive and antipyretic properties that may benefit ailing persons placed on the diet.

\section{MATERIALS AND METHODS}

\section{Plant material and extraction}

The fresh leaves of Vernonia amygdalina were collected between June and July (raining season) in the South Western part of Uganda. The leaf was identified by Julius Lejju (botanist) of the Biology Department, Faculty of Science, Mbarara University of Science and Technology. Specimen was retained with voucher number 16-20 in the Department. The plant leaves were shade air-dried and grounded into a coarse powder. Using a similar method as employed by ethnics, the dried coarse powder was sieved to a $2000 \mathrm{~g}$ fine powder and macerated for three hours in warm $\left(<80{ }^{\circ} \mathrm{C}\right)$ distilled water at a ratio of $131 \mathrm{~g}$ to 9 litres with intermittent shaking. The obtained extract was filtered while warm using a filter paper. The filtrate was further filtered using a 
buckner filter assemblage (aided by a suction pump) and subsequently dried using an oven (at $\leq 80{ }^{\circ} \mathrm{C}$ ) to obtain $360 \mathrm{~g}(18 \%$ yield) of residue. The obtained residue was stored in a desiccator for further use.

\section{Phytochemical screening}

Preliminary screening of the aqueous extract for the presence of phytochemicals was carried out using standard procedures (Harborne, 1973).

\section{Isolation of crude saponin}

The liquid-liquid extraction technique as described by Obadoni and Ochuko (2001) was adopted for the isolation. $20 \mathrm{~g}$ of the dried aqueous extract of $V$. amygdalina leaves dissolved in distilled water at a ratio of one to two was extracted thrice with diethyl ether (which was a half of the volume of the aqueous extract solution). The diethyl ether layer was discarded and the retained aqueous layer extracted further with $60 \mathrm{ml} \mathrm{n}$-butan-1ol (four times). The n-butan-1-ol extracts were bulked together and washed four times using $10 \mathrm{ml}$ of five percent $\mathrm{NaCl}$. The washed extract was concentrated at $<80{ }^{\circ} \mathrm{C}$ in an oven and air dried at room temperature to yield 1.81 g $(9.1 \% \mathrm{w} / \mathrm{w})$ of crude saponin residue. Using foaming test (Harborne, 1973), the residue was screened for saponin.

\section{Chemicals, drugs and test agents}

All the solvents (methanol, n-butanol, diethyl ether, chloroform and acetone), obtained from BDH sales representative in Kampala (Uganda) were of the analytical grade. Other agents used include acetic acid (Sigma-Aldrich, Germany) and active dry Saccharomyces cerevisiae: brewer's yeast (GRIFFCHEM $^{\circledR}$, Nairobi Kenya) was used to induce pyrexia in the antipyretic study. 300 $\mathrm{mg} / \mathrm{kg}$ acetylsalicylic acid (ASA) as reference standard, $5 \mathrm{ml} / \mathrm{kg}$ normal saline solution as placebo and crude saponin as test samples were used in all the experiments. Morphine sulphate (from project of Ministry of Health Molago, Kampala) as opioid reference standard at a dose of $5 \mathrm{mg} / \mathrm{kg}$ was used in the antinociceptive study.

\section{Animals}

120-200 g wistar rats (for antipyretic study) and $20 \mathrm{~g}-25 \mathrm{~g}$ albino mice (for acute toxicity and antinociceptive study) of both sexes which have been acclimatized in the animal facility of Mbarara University of Science and Technology were placed in standard cages where they were maintain on standard animal pellets (obtained from Nuvita Feeds Ltd., Kampala) and water ad libitum. The rats for antipyretic study were selected based on their measured basal anal temperature (using a thermistor probe) not exceeding $37{ }^{0} \mathrm{C}$, and achieving anal temperature elevation of at least $0.1{ }^{0} \mathrm{C}$ in response to intra peritoneal (i.p) administration of $15 \% \mathrm{w} / \mathrm{v}$ Saccharomyces cerevisiae at a dose of $10 \mathrm{ml} / \mathrm{kg}$ body weight. The animals for the antipyretic and antinociceptive studies were divided into five groups of five animals each and fasted overnight.

The National Institute of Health (NIH) guide for the care and use of laboratory animals approved by the Institutional Ethical Committee was adopted for the animal protocol in this study (NIH, 1978).

\section{Preparation and administration of drug}

All the standards and tests samples were prepared using sterile normal saline solution which also, served as placebo in the different experiments. Oral (p.o) administration was carried out using a canulasyringe assemblage, and hypodermic syringeneedle assembly used for intra-peritoneal (i.p) administration.

\section{Acute toxicity study}

The technique as described by Miller and Tainter (1944) with slight modification 
according to Ghosh (1984) adaptation was used. $50 \%$ lethality $\left(\mathrm{LD}_{50}\right)$ of the crude saponin was determined in a biphasic manner. Animals (albino mice) were starved but allowed access to water for twenty four hours prior to the study. In phase 1 , crude saponin doses $(500,1000,2000,4000,6000$ and 8000 $\mathrm{mg} / \mathrm{kg}$ p.o), using an animal for each dose $(\mathrm{n}=$ 1 ), were administered to establish the range of the expected $\mathrm{LD}_{50}$ dose. Based on data obtained, phase 2 investigatory step was done using more specific doses $(4000,4500,5000$ and $5500 \mathrm{mg} / \mathrm{kg}$ p.o) administered to four other groups of five animals each $(n=5)$. The investigations were repeated using i.p administration of 100, 200, 300, 400, 500 and $600 \mathrm{mg} / \mathrm{kg}$ in phase $1(\mathrm{n}=1)$; and 200,250 , 300 and $350 \mathrm{mg} / \mathrm{kg}$ in phase $2(\mathrm{n}=5)$.

In all the investigations, normal saline (o.p or i.p) administration to placebo group was used. After administration of each dose, the animals were observed continuously for two hours, occasionally for four hours further and finally, overnight mortality was recorded. $\mathrm{LD}_{50}$ was determined from the graph of probit (probit 5 being $50 \%$ mortality) against log dose of crude saponin.

\section{Antipyretic study}

Adopting standard procedure as described by a previous study, wistar rats earlier selected and induced pyrexia were randomly divided into five groups of five animals each (Okokon and Onah, 2004). The animals were allowed to starve overnight in their respective cages. Twenty hours after the administration of Saccharomyces cerevisae solution, the anal temperature of each animal was measured. Oral (p.o) administration of normal saline to group one, ASA to group two and crude saponin $(200,400$ and $600 \mathrm{mg} / \mathrm{kg})$ to groups three to five was immediately carried out after the anal temperature measurement. Four hours after the administration of the dose, the anal temperature of each animal was measured again.

\section{Antinociceptive study Writhing test}

Adopting literature documented technique, $0.6 \%$ acetic acid solution administered by intra peritoneal (i.p) route at a dose of $15 \mathrm{ml} / \mathrm{kg}$ was used to induce writhing (typical constriction response consisting of abdominal wall contraction, pelvic rotation and hind limb extension) 30 minutes after oral administration of acetylsalicylic acid (nonopioid standard), morphine sulphate (opioid standard), normal saline (placebo), $V$. amygdalina aqueous extract $(800 \mathrm{mg} / \mathrm{kg})$ or crude saponin $(600 \mathrm{mg} / \mathrm{kg})$ to the mice (Collier et al., 1968). Each mouse was returned to the cage. Five minutes after the administration of acetic acid, writhing counts were taken for five minutes under a double blind observation. Antinociceptive effects were measured by comparing their mean abdominal writhes count to the mean writhe count of the placebo group

$((\mathrm{c}-\mathrm{t}$ or $\mathrm{s}) / \mathrm{c}) \times 100$

NB: $\mathbf{c}$ is mean writhes count for placebo; $\mathbf{t}$ or $\mathbf{S}$ is mean writhes count for any of the tests or standards

\section{Hot plate test}

Prior to dose administration, the mice were selected on the basis of their basal reaction time (fore-paw licking or jumping off) when placed on the hot plate which was maintained at $55{ }^{\circ} \mathrm{C} \pm 1$. Animals with $\leq 8$ seconds reaction time were regarded as appropriate for inclusion (Shanmugasundaram and Venkataraman, 2005). 60 minutes after oral administration of acetylsalicylic acid, morphine sulphate, normal saline, $V$. amygdalina aqueous extract $(800 \mathrm{mg} / \mathrm{kg})$ or crude saponin $(600 \mathrm{mg} / \mathrm{kg})$, the mice were similarly exposed to the hot plate. Time taken for either fore paw licking or jumping off the hot plate was documented as reaction time. The group reaction time was taken as mean of the reaction times. 15 seconds was taken as cut off period to avoid damage to paws. Maximum possible analgesia (MPA) was calculated according to Idid et al. (1998): (( $\mathrm{T}_{1^{-}}$ $\left.\left.\mathrm{T}_{0}\right) /\left(15-\mathrm{T}_{0}\right)\right) \times 100$. 
$\mathrm{NB}: \mathrm{T}_{\mathbf{1}}$ is mean reaction time for standard or test; $\mathrm{T}_{\mathbf{0}}$ is mean reaction time for placebo

Cold tail flick test

Procedure as described by Pizziketti et al. (1985) was adopted for this test. Animals were considered for the study based on their latent period of tail-flick response. Prior to dose administration, two $\mathrm{cm}$ length of the animal's tail was immersed into a cold 1:1 mixture of water and ethylene glycol maintained at $-10{ }^{\circ} \mathrm{C}$ with an ultra low temperature freezer (UF 650 Napcoil, Thermo Electric Corporation). Animals with response $\leq 15$ seconds were selected. 60 minutes after oral administration of acetylsalicylic acid, morphine sulphate, normal saline, $V$. amygdalina aqueous extract $(800 \mathrm{mg} / \mathrm{kg})$ or crude saponin $(600 \mathrm{mg} / \mathrm{kg})$, animals were similarly exposed to the cold mixture of water and ethylene glycol. The response for each animal was taken as the elapsed time for tail deflection from the mixture. The first reaction time reading was discarded and the reaction time was taken as the mean of the last two readings. The response for each group was taken and documented as the mean of the reaction times. 30 seconds reaction cut-off period was used to avoid damage to the tail. The MPA was calculated as

$\left(\left(\mathrm{T}_{1}-\mathrm{T}_{0}\right) /\left(30-\mathrm{T}_{0}\right)\right) \times 100$

NB: $T_{1}$ is mean reaction time for standard or test; $T_{0}$ is mean reaction time for placebo

\section{Statistical analysis of data}

Results and calculations were based on the numerical expression of data as mean \pm SEM. Analysis of variance (ANOVA) was used to analyse values within groups and Student t-test, to analyse data between groups. $P \leq 0.05$ was taken as level of significance in all cases.

\section{RESULTS}

\section{Phytochemical screening}

Standard test for phytochemical constituents in the aqueous extract of the dried powdered leaves of $V$. amygdalina revealed the presence of saponins, alkaloids, sophisticated lactones, triterpenoids, reducing sugars, amino acids, flavonoids, terpenoids, tannins and cardiotonic glycosides.

\section{Acute toxicity study}

$\mathrm{LD}_{50}$ for the crude saponin using the i.p administration was $264.48 \mathrm{mg} / \mathrm{kg}$, while the p.o was $5152.3 \mathrm{mg} / \mathrm{kg}$. Abnormal gait and reduction in typical activities were observed prior to death with higher range of the doses used for the different routes of administration.

\section{Antipyretic study}

The statistical analysis of the antipyretic study using ANOVA indicated no significant $(P>0.05)$ variance in the yeast induced anal temperature within and among groups. The t-test analysis showed a dose dependent anal temperature decrease with crude saponin (Table 1) which was significant $(P \leq 0.05)$.

\section{Antinociceptive study}

Writhing Test: The acetic acid induced writhe count data for the standards, aqueous extract and crude saponin doses were significantly $(P \leq 0.05)$ different from normal saline (placebo group). However, the effect of antinociception was markedly observed with morphine sulphate at $89.69 \%$ and ASA at $86.60 \%$ (Table 2).

\section{Hot plate test}

Data obtained with this test showed significant $(P \leq 0.05)$ reaction time for the opioid standard and leaf aqueous extract (Table 3).

\section{Cold tail flick test}

Reaction time obtained with the cold tail flick test was significant $(P \leq 0.05)$ for morphine sulphate and the aqueous extract (Table 4). 
Table1: Decrease in the anal temperature of rats $4 \mathrm{hrs}$ after administration of doses.

\begin{tabular}{|c|c|c|c|c|}
\hline \multirow{2}{*}{ Group } & \multirow{2}{*}{ Dose } & \multicolumn{2}{|c|}{$\begin{array}{l}20 \mathrm{hrs} \text { after yeast administration } \\
\text { the anal Temp. }{ }^{0} \mathrm{C} \text { readings are }\end{array}$} & \multirow{2}{*}{$\begin{array}{c}\text { Dose Induced } \\
\text { Anal Temp. }{ }^{\circ} \mathrm{C} \\
\text { Decrease }\end{array}$} \\
\hline & & 0 hrs & $\begin{array}{c}4 \text { hrs (after } \\
\text { Dose admin.) }\end{array}$ & \\
\hline 1. placebo & $\begin{array}{c}\text { Normal saline } 5 \\
\mathrm{ml} / \mathrm{kg}\end{array}$ & $39.054 \pm 0.12$ & $39.04 \pm 0.11$ & $0.014 \pm 0.02$ \\
\hline 2. Standard & ASA $300 \mathrm{mg} / \mathrm{kg}$ & $39.10 \pm 0.11$ & $* 38.95 \pm 0.08$ & $0.15 \pm 0.04$ \\
\hline 3. Saponin & $200 \mathrm{mg} / \mathrm{kg}$ & $38.75 \pm 0.25$ & $* 38.62 \pm 0.24$ & $0.14 \pm 0.02$ \\
\hline 4. Saponin & $400 \mathrm{mg} / \mathrm{kg}$ & $38.78 \pm 0.19$ & $* 38.49 \pm 0.18$ & $0.29 \pm 0.01$ \\
\hline 5. Saponin & $600 \mathrm{mg} / \mathrm{kg}$ & $38.66 \pm 0.11$ & $* 38.29 \pm 0.11$ & $0.39 \pm 0.01$ \\
\hline
\end{tabular}

Table 2:Effect of $V$. amygdalina leaves' aqueous extract and crude saponin in the acetic acid induced writhing test in mice.

\begin{tabular}{lccc}
\hline Groups & Dose & $\begin{array}{c}\text { Mean Writhes } \\
\text { Count }\end{array}$ & $\begin{array}{c}\text { \% Antinociceptic } \\
\text { Effect }\end{array}$ \\
\hline 1. Placebo & Normal Saline $5 \mathrm{ml} / \mathrm{kg}$ & $19.4 \pm 2.51$ & 0 \\
2. Opioid Standard & morphine sulphate $5 \mathrm{mg} / \mathrm{kg}$ & $* 2 \pm 0.71$ & 89.69 \\
3. Non-opioid Standard & $300 \mathrm{mg} / \mathrm{kg}$ acetylsalicylic acid & $* 2.6 \pm 0.55$ & 86.6 \\
4. Aqueous Extract & $800 \mathrm{mg} / \mathrm{kg}$ & $* 5.6 \pm 0.89$ & 71.13 \\
5. Saponin & $600 \mathrm{mg} / \mathrm{kg}$ & $* 9.2 \pm 0.84$ & 52.58 \\
\hline
\end{tabular}

Data are mean \pm SEM value $(n=5)$ *Significantly $(P \leq 0.05)$ different from placebo group.

Table 3:Effect of $V$. amygdalina leaves' aqueous extract and crude saponin in the thermal stimulusinduced hot plate test in mice.

\begin{tabular}{lccc}
\hline Groups & Dose & $\begin{array}{c}\text { Mean Reaction Time } \\
(\mathbf{s e c})\end{array}$ & MPA \\
\hline 1. Placebo & Normal Saline $5 \mathrm{ml} / \mathrm{kg}$ & $5.49 \pm 0.07$ & 0 \\
2. Opioid Standard & morphine sulphate $5 \mathrm{mg} / \mathrm{kg}$ & $* 9.62 \pm 0.12$ & 43.39 \\
3. Non-opioid Standard & $300 \mathrm{mg} / \mathrm{kg}$ acetylsalicylic acid & $5.51 \pm 0.49$ & 0.21 \\
4. Aqueous Extract & $800 \mathrm{mg} / \mathrm{kg}$ & $* 7.90 \pm 0.74$ & 25.3 \\
5. Saponin & $600 \mathrm{mg} / \mathrm{kg}$ & $5.54 \pm 0.30$ & 0.02 \\
\hline Data are mean \pm SEM value $(\mathrm{n}=5)$. *Significantly $(P \leq 0.05)$ different from placebo group.
\end{tabular}


Table 4:Effect of $V$. amygdalina leaves' aqueous extract and crude saponin in the thermal stimulusinduced cold tail flick test in mice.

\begin{tabular}{|c|c|c|c|}
\hline Groups & Dose & Mean Reaction Time (sec) & MPA \\
\hline 1. Placebo & Normal Saline $5 \mathrm{ml} / \mathrm{kg}$ & $19.72 \pm 1.11$ & 0 \\
\hline 2. Opioid Standard & $\begin{array}{c}\text { morphine sulphate } 5 \\
\mathrm{mg} / \mathrm{kg}\end{array}$ & $* 26.24 \pm 1.29$ & 63.42 \\
\hline 3. Non-opioid Standard & $\begin{array}{c}300 \mathrm{mg} / \mathrm{kg} \text { acetylsalicylic } \\
\text { acid }\end{array}$ & $* 20.56 \pm 0.77$ & 8.17 \\
\hline 4. Aqueous Extract & $800 \mathrm{mg} / \mathrm{kg}$ & $* 22.74 \pm 0.90$ & 29.38 \\
\hline 5. Saponin & $600 \mathrm{mg} / \mathrm{kg}$ & $19.04 \pm 0.73$ & ${ }^{\#}-6.62$ \\
\hline
\end{tabular}

\section{DISCUSSION}

Vernonia amygdalina leaf has been used over the years by natives in the Eastern and Western part of Africa. The use of the leaf as food has always required a prior processing leading to the loss of possible medicinal principles (Adetuyi et al., 2008). In the current study, the antipyretic and antinociceptive properties of a major constituent of the leaf, saponin, usually lost during processing for food due to its aqueous solubility, was investigated.

In the study of the crude saponin activity against pyrexia, a common manifestation in many infectious diseases, the brewer's yeast was used as an exogenous stimulus. This is known to induce pyrexia, probably in a manner similar to lipopolyssacharides, in laboratory animals (Walter, 2003). Such induction commonly activates the arachidonic acid pathway associated with increase in prostaglandin $\mathrm{E}_{2}$ $\left(\mathrm{PGE}_{2}\right)$ (Kasper et al., 2008). A study by David et al. (2001) was able to show that inhibiting the arachidonic acid pathway and specifically, the activity of cyclo-oxygenase, results in the reduction of $\mathrm{PgE}_{2}$ level within the hypothalamus. Such inhibitory activity usually decreases elevated body temperature. The antipyretic activity test indicated that the crude saponin was able to significantly $(P \leq$ $0.05)$ decrease the yeast induced anal temperature elevation in the animals. This suggests that the crude saponin, like the standard, ASA possess inhibitory activity against the arachidonic acid pathway. Earlier studies shows that extract from the leaf, as well as the root, exhibits antipyretic activity (Okokon and Onah, 2004; Adiukwu et al., 2011). However, this study indicates that saponin is a major participant in the observed antipyretic activity of the herbal extract.

The antinociceptive study was carried out using the writhing, hot plate and cold tail flick test methods. In the writhing test, intra peritoneal administration of $0.6 \%$ acetic acid was used to induce pain in form of writhes, in the laboratory animals. The acid is considered to produce nociception by stimulating the release of various endogenous pain mediators peripherally (Raj, 1996). Such mediators usually excite the nociceptors and produce increase in the peritoneal fluid level of prostaglandins $\left(\mathrm{PgE}_{2}\right.$ and $\left.\mathrm{PgF}_{2 \alpha}\right)$ and lipooxygenase (Du et al., 2007). Initiation of the resulting slow and poorly localized pain is via the $\mathrm{C}$ fibres. Writhing test data showed that the aqueous extract and crude saponin, like the opioid and non-opioid standards, were able to significantly $(P \leq 0.05)$ decrease the number of writhes. This observation suggests the possession of inhibitory property by the aqueous extract and crude saponin against the activity of the endogenous pain mediators or their effect. Prior study shows that writhing test is limited by its lack of bias for either central or peripheral activity (Anoka et al., 2008). 
In hot plate (thermal) test, pain stimulus is initiated through the A $\delta$ fibres and inhibited centrally or interaction with the widely distributed opioid receptors peripherally (Raj, 1996). A significant $(P \leq$ $0.05)$ increase in the mean reaction time of the animals, indicating pain inhibition, was observed for the aqueous extract. This was similar but less to data obtained for the opioid standard, morphine sulphate. The hot plate technique has bias for centrally acting agents but not sufficiently sensitive to distinguish between opiates and non-opiates with central activity (Idid et al., 1998).

The cold tail flick test has been demonstrated to sufficiently identify opiates from non-opiates with central activity (Pizziketti et al., 1985). Obtained data using this technique showed that the aqueous extract produced a significant $(P \leq 0.05)$ increase in the mean reaction time, similar to morphine sulphate. This was not the same for the crude saponin.

Study finding supports previous data on the peripheral and central antinociceptive activity of Vernonia amygdalina leaf aqueous extract (Anoka et al., 2008). However, obtained data suggests that saponin may be responsible or contributory to the non-opioidlike peripherial antinociceptive property of the leaf aqueous extract. An earlier analgesic and anti-inflammatory in vivo study with Vernonia cinerea suggests the presence of phytochemicals like saponins to be responsible for observed antinociceptive property (Iwalewa and Adeboye, 2003).

Saponins are generally considered to be toxic with majority regarded to be powerful haemolytics in vitro. However, large doses may be needed to produce toxic effect when administered parenterally, and larger doses due to poor absorption when administered orally. Several toxicity tests have shown that the lethal oral dose of saponins is 3-1000 times as large as the lethal intravenous dose (George, 1965). As such, toxicity of saponins to warm blooded animals is dependent on the method of administration, source, composition, and concentration of the saponin mixture (Liu and Henkel, 2002). In this study, the $\mathrm{LD}_{50}$ data obtained for i.p administered crude saponin indicates approximately, twenty times more toxicity than the p.o administered dose.

In common terms, a $\mathrm{LD}_{50}$ dose of 2000 $\mathrm{mg} / \mathrm{kg}$ and above is categorized as unclassified and hence safe (OECD, 1987). Data obtained in previous studies (Anoka et al., 2008; Ojiako and Nwanjo, 2006) showed that the i.p administered aqueous extract of the leaf is moderately to slightly toxic (Ghosh, 1984). Study by Anoka et al., (2008) showed that the orally administered extract was slightly toxic in rats. Data in this study indicated that the crude saponin from the extract is practically non-toxic orally and moderately toxic intra-peritoneally.

Previous in vivo studies using rats, mice and rabbits showed that saponins are not absorbed in the alimentary channel but hydrolyzed to their corresponding sapogenins (aglycone) and sugar(s) by enzymatic action in the gastrointestinal tract (Güçlü-Ustündağ and Mazza, 2007; Gestetner et al., 1968). The readily more absorbable aglycone is because of this reason, usually considered to be responsible for most of the associated activities with the orally administered saponins. This may explain the safety of the orally administered saponin rich Vernonia amygdalina leaf aqueous extract in herbal therapy, or the consumption of the leaf as diet (Adiukwu et al., 2011).

\section{Conclusion}

The crude saponin from Vernonia amygdalina leaf aqueous extract, administered orally, has been shown by this study to possess substantial antipyretic and antinociceptive activity. However, the saponin constituent is known as one of the principles lost during processing of the leaf for food. In this regard, ailing persons with pyrexia and pains may benefit from the leaf of Vernonia amygdalina diet if processing technique is adapted to reduce loss of essential nutritional and medicinal constituents like saponin. Whereas data obtained in the current study 
may support the folkloric use of the herb by ethnics, the crude saponin is worth probing further for development into a phyto-drug with the hope that it will produce beneficial effect, similar to the herbal experience.

\section{ACKNOWLEDGEMENTS}

The authors are grateful to the Vice Chancellor of Mbarara University of Science and Technology (MUST), Prof. F.I.B Kayanja for his invaluable advice and input. We are grateful to Mr. P.J Adiukwu and Ms. Mabel Ebere for their technical input, the Faculty of Medicine Ethical Committee of Mbarara University of Science \& Technology for the review of the study proposal and also, the staff and management of Natural Chemotherapeutic Research Laboratories, Kampala for availing their facilities and time for this study.

\section{REFERENCES}

Adetuyi FO, Ajala L, Dada IBO. 2008. Effect of Processing Methods On The Chemical Composition and Antioxidants Potentials of Structium Sparejanophora (EwuroOdo) and Vernonia Amygdalina (Ewuro). Nig. Food J., 26(1): 133-140.

Anoka AN, Adzu B, Amon GA, Byarugaba D, Díaz-Llera S. 2008. The analgesic and antiplasmodial activities and toxicology of Vernonia amygdalina. J. Med. Food, 11(3): 574-580.

Bonsi MLK, Osuji PO, Tuah AK, Umunna NN. 1995. Vernonia amygdalina as a supplement to Teff Straw Fed to Ethiopian Menz Sheep. Agroforestry Systems, 31(3): 229-241.

Buttler GW, Bailey RW. 1973. Chemistry and Biochemistry of Herbage (vol.1). Academic Press: London and New York.

Collier H, Dinneen LC, Johnson CA, Schneider C. 1968. The abdominal constriction response and its suppression by analgesic drugs in mouse. $B r . J$. Pharmacol., 32: 295-310.

David M, Aronoff MD, Eric G, Neilson MD. 2001. Antipyretics: mechanisms of action and clinical use in fever suppression. A.J.M., 111(4): 304-315.

Du J, Yu Y, Ke Y, Wang C, Zhu L, Qian ZM. 2007. Ligustilide attenuates pain behaviour induced by acetic acid or formalin. J. Ethnopharmacol., 112: 211214.

George AJ. 1965. Legal status and toxicity of saponins. Food Chem. Toxicol., 3: 85-91.

Gestetner B, Birk Y, Tencer Y. 1968. Soybean saponins: fate of ingested soybean saponins and the physiological aspect of their hemolytic activity. J. Agric. Food Chem., 16: 1031-1035.

Ghosh MN. 1984. Toxicity Studies. Fundamentals of Experimental Pharmacology ( $2^{\text {nd }}$ edn). Scientific Book Agency: Calcutta; 153-158.

Güçlü-Ustündağ O, Mazza G. 2007. Saponins: properties, applications and processing. Criti. Rev. Food Sci. Nutrit., 47(3): 231258.

Harborne JB. 1973. Phytochemical Methods. Chapman and Hall: London; 113.

Idid SZ, Saad LB, Yaacob H, Shahimi MM. 1998. Evaluation of analgesia induced by mitragynine, morphine and paracetamol on mice. ARBEC., 4: 1.

Iwalewa OJ, Adeboye JO. 2003. Antianalgesic, antipyretic, antiinflammatory effect of methanol, chloroform and ether extracts of vernonia cinerea less leaf. J. Ethnopharmacol., 86: 229-234.

Izevbigie EB. 2005. Phytochemotherapy for cancer. United States Patent, Issued $6,849,604$.

Kasper DL, Fauci AS, Longo DL, Braunwald E. 2008. Harrison's Principles of Internal Medicine $\quad\left(17^{\text {th }}\right.$ edn). McGraw-Hill Professional; 117-121.

Liu J, Henkel T. 2002. Traditional Chinese Medicine (TCM): are polyphenols and saponins the key ingredients triggering biological activities. Curr. Med. Chem., 9: 1483-1485.

Miller LC, Tainter ML. 1944. Estimation of EC50 and its error by means of log-probit 
graph paper. Proc. Soc. Exp. Biol. Med., 57: 261-269.

Muir AD, Paton D, Ballantyne K, Aubin AJ. 2002. Process for recovery and purification of saponins and sapogenins from quinoa (Chenopodium quinoa). U.S. Pat. No. 6,355,249.

National Institute of Health. 1978. Guide for the Care and Use of Laboratory Animals. National Institute of Health (NIH publication No. 83-23): Bethesda, MD.

Obadoni BO, Ochuko PO. 2001. Phytochemical studies and comparative efficacy of the crude extracts of some homeostatic plants in Edo and Delta States of Nigeria. Global J. Pure and Appl. Sci., 8: 203-208.

Okokon JE, Onah MI. 2004. Pharmacological studies on root extract of Vernonia amygdalina. Nigeria J. Prod. \& Med., 8: 59-61.

Organization for Economic Cooperation and Development (OECD). 1987. Acute oral toxicity. Guidelines for the Testing of Chemicals, No. 401, Paris, France.

Patrice C, Laura JG, Jacqui T, Kamlesh K, Melanie JD. 2010. Fruit and vegetable intake and incidence of type 2 diabetes mellitus: systematic review and metaanalysis. BMJ., 341: c4229.

Pizziketti RJ, Pressman NS, Geller EB, Adler MW. 1985. Rat cold water tail-flick: A novel analgesic test that distinguishes opioid agonist from mixed agonistantagonist. Eur. J. Pharmacol., 119: 2329.

Raj PP. 1996. Pain mechanisms. In Pain Medicine; a Comprehensive Review. Mosby-Year Book: St. Louis, USA; 1224.

Ramaswamy S, Pillai NP, Gopalkrishnan V, Parmar NS, Ghosh MN. 1985. Analgesic effect of O-( $ß$ hydroxy ethyl) Rutoside in mice. Indian J. Exp. Biol., 23: 219-220.

Ridout CL, Price KR, DuPont MS, Parker ML, Fenwick GR. 1991. Quinoa Saponins: analysis and preliminary investigations into the effect of reduction by processing. J. Sci. food Agri., 54: 165176.

Shanmugasundaram P, Venkataraman S. 2005. Anti-nociceptive activity of Hygrophila auriculata (schum) heine. Afri. J. Trad., 2(1): 62-69.

Shi J, Konesh A, Yeung D, Kakuda Y, Mittal G, Jiang Y. 2004. Saponins from edible legumes: chemistry, processing, and health benefits. J. Med. Food, 7(1): 6778.

Walter F. 2003. Medical Physiology: A Cellular and Molecular Approach. Elsevier/Saunders; 58: 1300. 